Journal of Health Promotion and Behavior (2018), 3(2): 116-125

https://doi.org/10.26911/thejhpb.2018.03.02.05

\title{
Health Belief Model on the Predictors of Healthy Sex Behavior among Commercial Female Sex Workers in Surakarta, Central Java
}

\author{
Syarifah1), Argyo Demartoto' $^{2)}$, Ruben Dharmawan3) \\ 1)Masters Program in Public Health, Universitas Sebelas Maret \\ 2)Faculty of Social and Political Sciences, Universitas Sebelas Maret \\ 3)Faculty of Medicine, Universitas Sebelas Maret
}

\begin{abstract}
Background: Sexually transmitted infections (STIs) are diseases that are now a global issue because they are the entrance to HIV transmission. Female sex workers (WPS) have a high risk of contracting and transmitting STIs and HIV / AIDS due to unsafe sex behavior. The purpose of this study was to analyze the relationship of safe sex behavior for the prevention of sexually transmitted infections in female sex workers in Surakarta.

Subjects and Method: A cross-sectional study was conducetd in Surakarta, Central Java, from December 2017 to January 2018. A sample of 105 female sex workers was selected by fixed disease sample. The dependent variable was safe sex behavior. The independent variables were perceived susceptibility, perceived seriousness, perceived benefit, perceived barrier, perceive threat, cues to action, and self-efficacy. The data were collected by questionnaire and analyzed by a multiple logistic regression.

Results: Safe sex behavior among female sex worker increased with strong perceived benefit $(b=$ $0.18 ; 95 \% \mathrm{CI}=0.74$ to $0.28 ; \mathrm{p}=0.001)$ and strong self-efficacy $(\mathrm{b}=0.51 ; 95 \% \mathrm{CI}=0.25$ to 0.76 ; $\mathrm{p}<0.001)$. Safe sex behavior decreased with strong perceived barrier $(b=0.15 ; 95 \% \mathrm{CI}=-0.27$ to o.03; $\mathrm{p}=0.012$ ). Terdapat hubungan antara persepsi manfaat, efikasi diri dan persepsi hambatan dengan perilaku seks yang aman $\left(F=10.351 ; 95 \% \mathrm{CI}=6.70\right.$ to $\left.17.00 ; \mathrm{p}<0.001 ; \mathrm{R}^{2}=23.5 \%\right)$.

Conclusion: Safe sex behavior among female sex workers increases with strong perceived benefit and strong self-efficacy. Safe sex behavior decreases with strong perceived barrier.
\end{abstract}

Keywords: sex behaviour, safe sex, sexually transmitted infections, female sex workers

\section{Correspondence:}

Syarifah. Masters Program in Public Health, Universitas Sebelas Maret, Jl. Ir. Sutami 36 A, Surakarta 57126, Central Java. Email : syarifahsst@yahoo.co.id

\section{BACKGROUND}

Sexually transmitted infections (STIs) are diseases that are now a global issue because they are the entrance to HIV transmission. HIV continues to be a major public health problem in the world, until now it has caused 35 million people to die. In 2016, 1 million people died of HIV and up to now 36.7 million people are living with HIV with 1.8 million of them being new cases. From WHO data, $54 \%$ of adults and $43 \%$ of children live with HIV and must receive antiretroviral therapy for the rest of their lives. While for pregnant and lactating women, there are $76 \%$ of them who have HIV and have undergone antiretroviral therapy (WHO, 2017).

WHO makes a policy on STIs and HIV/ AIDS in a global strategy to face the STI 2016-2021. WHO (2016) explains that one way to achieve SDGs 2030 at point 3 is to implement a global strategy in dealing with STIs. Because, a healthy society can increase productivity and support in achieving prosperity in the community. 
One-time sexual intercourse can transmit STIs if done with people who are already infected. There are STIs that are easily cured and there are some that are difficult or even incurable. The result of contracting STIs include prolonged pain, sterility and being unable to get pregnant. People who have contracted STIs are more easily infected with HIV which will then develop into AIDS (Unicef, 2012).

The results of the 2013 Integrated Biological and Behavioral Survey by DG P2PL (2014) state that the population is most at risk for contracting and transmitting HIV and STIs consisting of FSW, men at high risk potential (truck driver, sailor, and laborers), gay, and injecting drug user.

In the final report by the Director General of P2P, Ministry of Health of the Republic of Indonesia (2017), throughout 2016, the number of IMS service visits in Indonesia was 441,704 with the highest percentage of others 192,786 (43.6\%); Risti pair 93,520 (21.2\%); WPS 89,792 (20.3\%); LSL 39,681 (9\%); PS customer 14,043 (3.2\%); Waria 6,951 (1.6\%); IDU 4,425 (1\%) and PPS 506 (0.1\%). The number of STI cases with diagnosis enforcement based on the syndrome approach and laboratory examination according to the high risk group is 9,300 WPS (29.13\%); Others 9,022 (28.26\%); IDU 7,076 (22.16\%); PS 4,030 customers (12.62\%); 1,400 PPS (4.38\%); LSL 676 (1.12\%); Transvestite 334 (1.05\%); Risti pair 87 (0.27\%).

From the data presented, WPS (Female Sexual Workers) are included in the top 3 in the number of STI service visits and are in the top position in establishing STI diagnoses from laboratory examinations. It can be concluded that every FSW who visits STIs, has the highest risk of getting STIs.
In the 2013 IBBS study by DG P2PL, the highest chlamydia prevalence was observed in FSW (40.4\%). Gonorrhea prevalence was highest in FSW (32.4\%). The results of the preliminary study conducted at the Surakarta AIDS Commission (2017) showed that the data from October 2005 to December 2016, there was 2,259 cases with 754 cases of HIV, 1,505 of AIDS, and 551 were death. STIs case in 2017, 150 were laboratory diagnosed STIs including 92 cervicitis, 9 gonnorhea, 4 urethritis, 3 syphilis, and 1 trichomoniasis.

In Surakarta, the number of FSW in 2016 was 268 in 10 hotspots, and for WPSTL spread in 13 hotspots amounted to 180. This number is already a high number considering the population is only 490,214 people. This amount increases the risk of STI and HIV transmission to FSW customers, sexual partners and children. In the STBP findings in high-risk groups in Indonesia (2007) stated that the prevalence of STIs was very high in WPSL and was quite high in WPSTL and based on the province, between $6 \%-16 \%$ WPSL and $2 \%$ 9\% WPSTL had been infected with HIV. Most WPS have been infected during the first six months of selling sex.

Basically, health behaviors are determined by personal beliefs or perceptions about the disease and the strategies to reduce the occurrence of a disease. Personal perception is influenced by a variety of factors that influence an individual's health behavior. Efforts that exist in the individual to determine what is best for him include how someone feels or believes that he is susceptible to a disease or danger / seriousness of illness that can be suffered by someone (Berg et al., 2011).

FSW is a high risk of contracting and transmitting STIs and HIV / AIDS. WPS transmission and STI and HIV / AIDS methods are not only when working with 
sexual contact with customers but also as a wife and as a mother of her children. Servin et al. (2017) states that the risk of STI transmission is higher in mothers who work as FSWs due to economic pressure, and influences the vulnerability of FSW in making decisions such as drinking alcoholic beverages, not using condoms in serving their customers and not maintaining their health. Several studies have confirmed that FSW have not entirely used the principle of safe sex in their work.

The theory of behavior change at the individual level is often referred to as the Health Belief Model (HBM). Behavioral change is divided into 3 (three) parts, namely the first individual perception which consists of perceived susceptibility/ vulnerability, perceived seriousness/ severity, perceived threat perception, perceived benefit), perceived barriers, perceived cues to action and self efficacy. Then the second one is modifying the factors, and the third is action (likelihood of action) (Burke, 2013; Sulaeman, 2016).

The purpose of this study was to analyze the relationship of safe sex behavior for the prevention of sexually transmitted infections in female sex workers in Surakarta using Health Belief Model theory.

\section{SUBJECTS AND METHOD \\ 1. Study Design \\ This was an analytic observational study with a cross sectional design. The study was conducted in Surakarta, from December 2017 to January 2018.}

\section{Study Population and Sample}

The population of this study were female sex workers (FSW) in Surakarta. FSW who live in Surakarta and are spread in Direct WPS hotspots and Indirect WPS hotspots. The sample size was 105 subjects, using fixed disease sampling. With the ratio of the number of case control respondents to $1: 2$, the number of FSW who experienced STIs was 35 (cases) and the number of FSW who did not experience STIs was 70 (controls).

\section{Study Variables}

The dependent variable was safe sex behavior. The independent variables was perceived susceptibility, severity, benefit, barrier, and threat, self-efficacy, and cues to action.

\section{Operational Definition of Variables}

Perceived susceptibility was defined as subjective individual belief to feel vulnerable or have the possibility of experiencing STIs. The more individuals perceive that they are at risk, it will make the individual perceive it as a threat and will take a treatment. The data were collected by questionnaire. The measurement scale was continous.

Perceived benefit was when an individual assesses that when he has a safe sex behavior he will get an advantage, for example, he will be healthier and can reduce the perceived risk. The data were collected by questionnaire. The measurement scale was continous.

Perceived barrier occurs when individuals face obstacles when doing safe sex properly such as costs (buying condoms, clean cloth, self-examination), psychological consequences (afraid of being said to be sick if doing a check-up, embarrassment when consulting about how to do genital cleansing appropriately), consideration physical (distance of the bathroom or distant source of running water so that it is difficult to achieve it) it will make individuals have risky sexual behavior. The data were collected by questionnaire. The measurement scale was continous.

Perceived threat was defined as individual's beliefs to feel threatened to experience STIs. The more individuals perceive that the disease is at risk, it will make the individual perceive it as a threat 
and will soon take a treatment. The data were collected by questionnaire. The measurement scale was continous.

Cues to action was defined as a warning or notice related to health problems can potentially increase the tendency of individuals to perceive it as a threat and will immediately take an action. Cues to action include various forms such as public service advertisements about the dangers of STIs, articles in newspapers, and others. The data were collected by questionnaire. The measurement scale was continous.

Self-efficacy was defined as the ability to feel the ability to do an action. The data were collected by questionnaire. The measurement scale was continous.

\section{Data Analysis}

The characteristics of continuous data are described in $\mathrm{n}$, mean, and max. The characteristics of categorical data are described in

Table 1. Univariate Analysis

\begin{tabular}{llcc}
\hline Characteristics of Study Subjects & $\mathbf{n = 1 0 5}$ & $\mathbf{\%}$ \\
\hline Age & Under 26 & 17 & 16.2 \\
& $26-35$ & 57 & 54.3 \\
\multirow{3}{*}{ Educational background } & 31 & 29.5 \\
& Above 35 & 1 & 1.0 \\
\multirow{4}{*}{ Condom Use } & No formal education & 93 & 88.6 \\
& <Senior high school & 11 & 10.5 \\
& 2Senior high school & 79 & 75.2 \\
& The last a week & 23 & 21.9 \\
Going to the clinic & The last a month & 1 & 1.0 \\
STIs & The last six months & 2 & 1.9 \\
& Never & 8 & 7.6 \\
& Never & 97 & 92.4 \\
\hline
\end{tabular}

A total of $88.6 \%$ of the research subjects did not have a job other than being a WPS. Judging from the length of work, $94.3 \%$ of them have more than 6 months of profession as FSW with more than 5 customers amounted to $91.4 \%$. The number of female sex workers who were the subject of this study amounted to $92.4 \%$ of the research subjects had income above the UMR, with the highest number of $64.8 \%$ $\mathrm{n}$, and percent (\%). The relationship between the independent and dependent variables were analyzed by multiple linear regression.

\section{Research Ethics}

This study has obtained the ethical clearance from the Dr. Ethical Health Research Ethics Commission. Moewardi Surakarta number: 1.043 / XI / HREC / 2017 dated November 15, 2017.

\section{RESULTS}

\section{Univariate Analysis}

Based on Table 1, it can be seen that the age of the study subjects varies with the dominant ones of the age between 26 to 35 years, which is $54.3 \%$. The last education which the largest study subjects have is elementary and junior high school, at $88.6 \%$. $56.2 \%$ of the study subjects were widows. having more than 2 partners and $67.6 \%$ having children less than 2 children.

Research subjects stated that 51.4\% had sexual intercourse for the first time when they were under 18 years old and $64.8 \%$ of the study subjects were having their last sexual intercourse less than 24 hours. Study subjects who used condoms last week were $75.2 \%$. 92.4\% of the FSW who become repondents have checked into an STI clinic, which means that WPS 
Journal of Health Promotion and Behavior (2018), 3(2): 116-125

https://doi.org/10.26911/thejhpb.2018.03.02.05

awareness of the dangers of sexually

transmitted infections is high enough.

Table 2. The Description of Study Variables

\begin{tabular}{lccccc}
\hline \multicolumn{1}{c}{ Variable } & N & Mean & SD & Min. & Max. \\
\hline Safe Sex Behavior & 105 & 17.55 & 1.792 & 14 & 23 \\
Seriousness & 105 & 21.35 & 2.139 & 17 & 26 \\
Barrier & 105 & 28.30 & 2.885 & 23 & 33 \\
Benefit & 105 & 23.58 & 3.201 & 14 & 35 \\
Threat & 105 & 27.29 & 3.304 & 22 & 35 \\
Cues to Action & 105 & 18.05 & 4.640 & 10 & 27 \\
Self-efficacy & 105 & 11.27 & 1.273 & 8 & 15 \\
\hline
\end{tabular}

Table 2 showed the descriptive statistics for each variable including minimum score, maximum score, mean score, and standard deviation. Mean described the average score, while the standard deviation (SD) described how far the data varies. If the score of SD was low, it mean that the data was representative

\section{Bivariate Analysis}

Bivariate analysis described about the effect of one independent variable on one dependent variable. Bivariate analysis showed the effect of independent variables (suscepti- bility, seriousness, benefit, barrier, selfefficacy, and cues to action) with dependent variable (safe sex behavior).

Table 3 showed that perceived seriousness $(\mathrm{r}=0.10, \mathrm{p}=0.789)$, perceived benefit $(\mathrm{r}=0.92, \mathrm{p}=0.104)$, perceived threat $(\mathrm{r}=90, \mathrm{p}=0.122)$, cues to action $(\mathrm{r}=0.79, \mathrm{p}=$ 0.334 ), and self-efficacy ( $\mathrm{r}=0.81, \mathrm{p}=0.000$ ) have a positive and statistically significant effect on safe sex behavior. While perceived barrier $(\mathrm{r}=-1.20, \mathrm{p}=0.017)$ has a negative and statistically significant effect on safe sex behavior.

Table 3. Bivariate Analysis on the Determinants of Safe Sex Behavior

\begin{tabular}{lcc}
\hline \multicolumn{1}{c}{ Independent Variables } & $\mathbf{r}$ & $\mathbf{p}$ \\
\hline Seriousness & 0.10 & 0.789 \\
Barrier & -1.20 & 0.017 \\
Benefit & 0.92 & 0.104 \\
Threat & 0.90 & 0.122 \\
Cues to Action & 0.79 & 0.334 \\
Self-efficacy & 0.81 & 0.000 \\
\hline
\end{tabular}

\section{The Result of A Multiple Linear Regression}

From the result of Table 4, there was a positive effect between perceived barrier and safe sex behavior $(b=0.15 ; 95 \% \mathrm{CI}=-$
0.27 to $-0.03 ; \mathrm{p}=0.012)$. There was a positive effect of perceived benefit on safe sex behavior among female sex workers $(\mathrm{b}=$ $0.18 ; 95 \% \mathrm{CI}=0.74$ to 0.28 ; $\mathrm{p}<0.001$ ).

Table 4. The results of multiple linear regression

\begin{tabular}{lcccc}
\hline \multicolumn{1}{c}{$\begin{array}{c}\text { Independent } \\
\text { Variables }\end{array}$} & \multirow{2}{*}{$\mathbf{c}$} & \multicolumn{2}{c}{$\mathbf{9 5 \%}$ CI } & \multirow{2}{*}{$\mathbf{p}$} \\
\cline { 3 - 4 } (Constant) & 11.85 & Lower Limit & Upper Limit & $<0.001$ \\
Barrier & -0.15 & -0.26 & 17.00 & 0.012 \\
Benefit & 0.18 & 0.08 & -0.03 & $<0.001$ \\
Self-efficacy & 0.51 & 0.25 & 0.28 & $<0.001$ \\
N observation $=105$ & & $\mathrm{R}^{2}=0.235$ & 0.76 & \\
Adjusted $\mathrm{R}^{2}=0.212$ & & $\mathrm{p}<0.001$ & & \\
\hline
\end{tabular}


There was a positive effect of selfefficacy on safe sex behavior among female sex workers. The stronger a person's selfefficacy, the stronger the safe sex behavior among female sex workers $(b=0.51 ; 95 \%$ $\mathrm{CI}=0.25$ to $0.76 ; \mathrm{p}<0.001)$.

\section{DISCUSSION \\ 1. The relationship between percei- ved barrier and safe sex behavior among female sex workers}

The result showed that there was a significant effect between perceived barrier and safe sex behavior. High perceived barrier would reduce safe sex behavior. This results was supported by Bauermeister et al. (2014) about the barrier among MSM about safe sex behavior which was the high cost of insurance and health services. Low awareness also prevented MSM from having safe sex behavior, in addition, MSM who have never been exposed to STD felt that they were safe and did not need to have safe sex behavior.

A study conducted in Kermanshah, West Iran, in 2014 about the application of health belief models stated that perceived barrier was one of the factors that affect safe sex behavior. Sexual partners felt dissatisfied with the use of condoms as one of the safe sex behaviors because it reduced the sense of trust between partners (Kabodi et al., 2014).

A study done by Lou and Chen (2009) stated that there was a significant relationship between someone's attitude and risky sexual behavior. A study by Anyanwu et al. (2013) stated that the barriers in safe sex behavior were costs and the availability of condoms. Stigma and discrimination, including concerns of different treatment at health service providers were a major barrier to safe sex behavior. Increasing the knowledge, social support, and recognition of female sex workers in the role of women in society that appeared as facilitators could reduce the barriers in safe sex behavior (Chanda et al., 2017).

The health stigma was often referred as an obstacle of female sex workers in conducting health checks and being a barrier to safe sex behavior. In addition, relating to social stigma and experience experienced by FSW, it could lead to a barrier for FSW. Interventions that can be done, namely a comprehensive approach could reduce the negative stigma about health and social services to FSW, therefore, FSW want to have safe sex behavior and go to health services (Kim et al., 2018).

Based on several studies that have been stated, it can be concluded that perceived barriers have an inverse effect on safe sex behavior. The higher the barriers experienced by FSW, the lower the safe sex behavior. The lower the barrier experienced by FSW, the higher the safe sex behavior.

\section{The relationship between percei- ved benefit and safe sex behavior among female sex workers}

From the result of this study, it can be concluded that there was a significant effect between perceived benefit and safe sex behavior among FSW.

Health Belief Model theory (Rosenstock, 1988 in Ika, 2015) stated that perceived benefit was how individuals assessed the benefits when health behaviors were suggested, so that the individuals would have safe sex behavior.

This was in line with a study by Enggarwati (2015) which stated that there was a relationship between perceived benefit and prevention behavior of HIV/ AIDS transmission. The higher the perceived benefits of the prevention of STD and HIV \& AIDS, the better the practice in the prevention of STD and HIV \& AIDS.

A study done by Schneider (2009) in truck drivers who were the customers of 
FSW in Andhra Pradesh, South India, stated that there was an enhancement in the awareness of truck drivers after knowing the risks of sexual contact behavior with FSW. They knew the benefits of maintaining genital hygiene and washing their hands after sexual contact. Behavioral changes can occur among truck drivers to prevent the disease symptoms by controlling the STD risk factors to reduce morbidity and mortality due to STD and HIV/ AIDS.

A study done by Yi et al. (2018) was evaluating the effectiveness of behavioral interventions in increasing loyal behavior to partners and safe sex between active heterosexuals. The result of the study was that women tend to have greater achievement in condom use and were loyal to their partners, this was due to the benefits that can be obtained from safe sex behavior.

The statements about the perceived benefits on safe sex behavior were strengthened by a study conducted by Yuan et al., (2017) which stated that benefits of condom use and self-efficacy could lead to a belief to be consistent in condom use. This was possible because of the intervention program about the benefits of the condom use as a safe sex behavior.

The beliefs in the benefits of safe sex behavior include reducing the risk of contracting STD, preventing pregnancy, and preventing HIV transmission. This increase a consistent safe sex behavior (Widdice et al., 2006).

The result of a study by Parson et al. (2000) stated that safe sex behavior was supported by their perception of positive benefits associated with risky behavior, rather than knowing the costs or dangers that can occur with risky sex behavior.

Female sex workers in Savannakhet, Laos could find out that risky sex behavior can increase the chances of contracting STD and HIV. The risk was grouped and they figured the ways to deal with the risks that increased the transmission of STD and HIV. Therefore, they tried to have safe sex behavior with a number of strategies, including: refusing unprotected sex, not using client's condoms, providing condoms, refusing oral or anal sex, asking clients to use condoms, using contraception, refusing to drink, etc. (Phrasisombath et al., 2012).

From several existing studies, it can be concluded that perceived benefits was in line with safe sex behavior. The higher the benefits obtained by having a safe sex behavior, the higher the effort to have safe sex behavior. FSW in Surakarta could compare that the number of the risk and the barrier was not comparable to the benefits that would be obtained by having a safe sex behavior. Then, they made a decision for themselves to have safe sex behavior.

\section{The relationship between self- efficacy and safe sex behavior among female sex workers}

The result showed that there was a significant effect between self-efficacy and safe sex behavior among FSW. Stronger self-efficacy, the stronger the safe sex behavior.

A study done by Benoit et al. (2017) stated that sex workers have a complex relationship between work as a sex worker and their self-awareness, one of them was in the aspect of self-efficacy. The majority of sex workers explained various dimensions of self-esteem and how sex gave positive and negative effects on their selfawareness in sexual behavior. Sex workers have a negative impact on self-esteem due to a low sense of personal value, and were not socially accepted by the community. On the other hand, it has a positive effect on themselves to maintain their reproductive health. 
According to experimental research conducted by Ghosal et al. (2003) on sex workers in Kolkata, India. There were 203 sex workers who felt that the sex worker psychological empowerment program increased their self-confidence and selfesteem. Sex workers found a positive effect after psychologically viewing themselves as having low self-esteem because they were isolated, then it could bring self-confidence and self-efficacy. Eventually, there was a desire to have a good future with safe sex behavior to maintain self-health, have savings for the future, and inventory in education.

The psychological literature define "agent" (self-efficacy) as a belief about someone's ability to achieve a task or goal (Bandura, 1982).

Choice, effort, and perseverance in dealing with problems were all affected by a sense from the body (Bandura, 1991). If someone believed that certain results were beyond their ability, he/she would not try to achieve them, even though he/she has a strong belief in the action (Boyd and Vozikis, 1994). One of the ways to convince someone was by giving persuasion or advice. If someone was given a realistic argument, then it would give a strong encouragement to live and exert the effort so that it can be accomplished (Wood and Bandura, 1989).

There was a study conducted in Burkina Faso on 350 FSW and 330 MSM about the stigma that emerged about health services for FSW and MSM. The results of the study stated that they received a lot of bad stigma such as verbal abuse, being rejected by their friends, the police refused to protect them, felt embarrassed to walk in public, and were afraid to go to health services. This was closely related to low self-efficacy because of the negative stigma that they received. So that FSW and MSM refused to take proper sexual behavior and go to health services (Kim et al., 2017).

There was a study on 63 peer review publications which related to self-efficacy about male and female sexual behavior. The data found that self-efficacy about sex affected self-confidence and could predict sexual behavior. Men have higher selfefficacy to use condoms than women. And women have higher self-efficacy in refusing to have sex than men. This proved that selfefficacy as the ability to refuse to have sex affected safe sex behavior in women (Closson et al., 2018)

A qualitative study conducted in Nepal stated that female sex workers who have low self-efficacy tend to have unsafe sex behavior. Low self-efficacy was caused by the intimidation and violence done by the police, intimacy with partners and clients so that FSW found the difficulty to ask a partner to use condoms. The cooperation of government and NGO could increase FSW's confidence in the community, which then increased self-efficacy, general welfare, and reduced the risk at work (Ghimire, 2011).

Based on the descriptions above, it can be concluded that there was a positive effect between perceived benefits and selfefficacy with safe sex behavior, and was inversely proportional between perceived barriers and safe sex behavior. Therefore, the results of the study were in accordance with the previous studies and support the theory of health belief model.

\begin{tabular}{l}
\hline \multicolumn{3}{c}{ REFERENCE } \\
\hline Bauermeister, Jose, Meanley, Steven, \\
Pingel, Emily, Soler, Jorge, Harper, \\
Gary W (2013). PrEP awareness and \\
perceived barriers among single \\
young men who have sex with men in \\
the United States. Curr HIV Res. 2013 \\
Oct; 11(7): 520-527
\end{tabular}


Bandura A (1982). Self-efficacy Mechanism in Human Agency. American Psychologist. 37(2): 122-147.

(1991). Social Cognitive Theory of Self-Regulation. Organizational Behavior and Human Decision Processes, $50(2), 248-287$.

Benoit C, Smith M, Hasson M, Magnus S, Flagg J, Maurice R (2017). Sex work and three dimensions of self-esteem: self-worth, authenticity and self-efficacy. Cult Health Sex. 20(1): 69-83. doi:10.1080/13691058.2017.1328075.

Berg AO, Melle I, Rossberg JI, Romm KL, Larsson S, Lagerberg TV, Hauff E (2011). Perceived discrimination is associated with severity of positive and depression/anxiety symptoms in immigrants with psychosis: a crosssectional study. BMC Psychiatry, 11(1): 77. http://doi.org/10.1186/1471244X-11-77.

Boyd NG, Vozikis GS (1994). The Influence of Self-efficacy on the Development of Entrepreneurial Intentions and Actions. Entrepreneurship Theory and Practice, 18(4): 63-77.

Chanda MM, Perez-Brumer AG, Ortblad KF, Mwale M, Chongo S, Kamungoma N, Kanchele C et al. (2017). Barriers and Facilitators to HIV Testing Among Zambian Female Sex Workers in Three Transit Hubs. AIDS Patient Care STDS. 31(7): 290-296. doi: 10.1089/apc.2017.0016.

Closson K, Lachowsky N, Nkala B, Dietrich JJ, Palmer A, Cui Z, Beksinska M et al. (2018). Sexual Self-Efficacy and Gender: A Review of Condom Use and Sexual Negotiation Among Young Men and Women in Sub-Saharan Africa. J Sex Res. 55(4-5):522-539. doi: 10.1080/00224499.2017.1421607.
Dirjen P2P Kemenkes RI (2014). Survei Terpadu Biologis dan Perilaku 2013. Kemenkes RI. (2017). Final Report of HIV-AIDS and STI Cases in Indonesia 2016. Indonesian Ministry of Health. Jakarta. Retrieved from http://www.aidsindonesia.or.id/ck_uploads/files/ Final Laporan HIV AIDS TW 4 2016.pdf

Anyanwu FC, Goon DT, Tugli A, Olukoga A, Amusa LO, Netshikweta ML, Maphula A (2013). African Journal for Physical Health Education, Recreation and Dance Perceived barriers to protected sexual intercourse among University of Venda students. African Journal for Physical Health Education, Recreation and Dance, 19(4): 786 - 799.

Ghosal S, Jana S, Mitra NMS, Roy S (2013). Sex Workers, Stigma and Self-Belief: Evidence from a Psychological Training Program in India. CAGE Working Paper. 152: 1-42.

Ghimire L, Smith W, Cairns S, Teijlingen, Edwin R, Dahal R, Luitel NP (2011). Reasons for non- use of condoms and self-efficacy among female sex workers: a qualitative study in Nepal. Health Promot Perspect. 7(2): 74-79. doi: 10.15171/hpp.2017.14.

Kim HY, Ky-Zerbo G, Lougue M, Stahlman, Samadoulougou, Ouedraogo, Kouanda, Listman, Baral (2017). Stigma as a barrier to health care utilization among female sex workers and men who have sex with men in Burkina Faso. Epidemiol. 28(1):13-19. doi: 10.1016/j.annepidem.2017.11.009.

Kim HY, Grosso A, Ky-Zerbo O, Lougue M, Stahlman S, Samadoulougou C, Ouedraogo G, et al. (2017). Stigma as a barrier to health care utilization among female sex workers and men 
who have sex with men in Burkina Faso.

Komisi Penanggulangan AIDS (KPA) Provinsi Jawa tengah (2015). HIV \& AIDS. Retrieved from: http://birohumas.jatengprov.go.id/ppid/wpcontent/uploads/2016/o1/BUKU-

SAKU-KPA-2015.pdf

Komisi Penanggulangan AIDS (KPA) Kota Surakarta (2016). Data kasus HIV/ AIDS Surakarta. KPA: Surakarta. (2017). Capaian kasus KPA Kota Ska 2017. KPA: Surakarta.

Kabodi S, Barati M, Gilan NR, Sohyla R (2014). Application of the Health Belief Model for Investigation of Couples Attitude toward Sexual Health. Health Education and Health Promotion (HEHP). 2(3).

Lou JH, Chen SH (2009). Relationships among sexual knowledge, sexual attitudes, and safe sex behaviour among adolescents: a structural equation model. Int J Nurs Stud. 46(12): 1595603. doi: 10.1016/j.ijnurstu.2009.05.017.

Ng JYS, Chan RKW, Chio MT, Lim RBT, Koh D, Wong ML (2018). An Abstinence and Safer Sex Intervention for Adolescents Attending the Public Sexually Transmitted Infection Clinic in Singapore. Journal of Adolescent Health, 62(6): 737-746.

Parson JT, Halkitis PN, Borkowski T, Bimbi D (2000). Perceptions of the benefits and costs associated with condom use and unprotected sex among late adolescent college students. J Adolesc. 23(4): 377-91.PMID:10936012. DOI : 10.1006/jado.2000.0326

Phrasisombath, Ketkesone, Faxelid, Elisabeth, Sychareun, Vanphanom, Thomsen, Sarah (2012). Risks, benefits and survival strategies-views from female sex workers in Savannakhet, Laos.
BMC Public Health. 12: 1004. doi: 10.1186/1471-2458-12-1004.

Servin AE, Reed E, Brouwer KC, MagisRodriguez C, Boyce S, Strathdee SA, Silverman JG (2017). Motherhood and Risk for Human Immunodeficiency Virus/ Sexually Transmitted Infections Among Female Sex Workers in the Mexico-US Border Region. Sexually Transmitted Diseases. http://doi.org/10.1097/OLQ.000000000o000634.

Sulaeman ES (2014). Promosi Kesehatan: Teori dan Implementasi di Indonesia. Surakarta: UNS Press

Unicef (2012). Mengenal dan Menghadapi Masalah HIV/AIDS. Retrieved from https://www.unicef.org/indonesia/id /HIV-AIDSbooklet_part3.pdf

WHO (2016). Global Health Sector Strategy on Sexually Transmitted Infections 2016-2021. World Health Organization.

(2017). Fact Sheet VIV/AIDS, 1-7. Retrieved from http://www.who.int/mediacentre/factsheets/fs36o/en/. (2107). International travel and health: HIV/AIDS and other sexually transmitted infections. http://www.who.int/ith/diseases/hivaids/en/.

Widdice LE, Cornell JL, Liang W, HalpernFelsher, Bonnie L (2006). Having Sex and Condom Use: Potential Risks and Benefits Reported by Young, Sexually Inexperienced Adolescents. Journal of Adolescent Health, 39: 588 -595.

Xu Y, Chen X, Yu B, Joseph V, Stanton B (2017). The effects of self-efficacy in bifurcating the relationship of perceived benefit and cost with condom use among adolescents: A cusp catastrophe modeling analysis. J Adolesc. 61: 31-39. doi: 10.1016/j.adolescence.2017.09.004. 